\title{
Bio-Physicochemical Studies on Water Calyx Fluid in the African Tulip Tree, Spathodea campanulata P. Beauv.
}

\author{
Martin Paul A'*, Jayanthi D', Thamizhseran $\mathbf{N}^{2}$
}

Martin Paul $A^{1, *}$, Jayanthi $D^{1}$, Thamizhseran $\mathrm{N}^{2}$

${ }^{1}$ Research Scholar, R\&D Centre, Bharathiar University, Coimbatore-641 046, INDIA. ${ }^{2}$ Associate Professor, Department of Botany, St. Joseph's College (Autonomous), Bengaluru-560 027, INDIA.

\section{Correspondence}

Martin Paul A

Research Scholar, R\&D Centre, Bharathiar University, Coimbatore - 641 046, Tamil Nadu, INDIA.

Tel. +91 8105710701

E-mail: mart_paul18@yahoo.com

History

- Submission Date: 29-03-2019;

- Review completed: 08-04-2019;

- Accepted Date: 15-04-2019.

DOI : 10.5530/pj.2019.11.94

Article Available online http://www.phcogj.com/v11/i3

Copyright

(C) 2019 Phcogj.Com. This is an openaccess article distributed under the terms of the Creative Commons Attribution 4.0 International license.

\begin{abstract}
Background: Flowers of Spathodea campanulata P. Beauv. development is unique as inner whorls develop immersed in a fluid called water calyces. Purpose: The present study is an investigation into the biochemical composition and physicochemical properties of water calyx fluid from Spathodea campanulata P. Beauv. Methods: Fluid composition of small, medium and large stages of $S$. campanulata flower buds were analyzed qualitatively and quantitatively for biomolecules viz., reducing sugars, total free amino acids, proteins, phenols and Indole3-Acetic Acid (IAA). Physiochemical analyses were done using particle size analyzer. Results: Reducing sugars, total free amino acids, proteins and IAA were present in appreciable amounts whereas total phenol content was low and the content of biomolecules were significant between groups and within the groups. The water calyx fluid is highly stable and absolute necessity for the floral development. Conclusions: The concentrations of all the analyzed biomolecules were found to be decreasing with bud maturity. The contents of water calyx fluid is obligatory for the development of floral whorls.
\end{abstract}

Keywords: Water calyx fluid, Biochemical composition, Zeta potential.

\section{INTRODUCTION}

The phenomenon of flowering in plants is one of the most explored areas in the field of reproductive biology which is governed by both endogenous and exogenous metabolites. Floral whorls in the African tulip tree, Spathodea campanulata P. Beauv. develop inside the closed gamosepalous calyx submerged in the watery fluid often referred to as water calyces or water jacket. The presence of water calyx in S. campanulata was ascribed to be beneficial in the floral development and the liquid is reported to be alkaline in nature with traces of hydrochlorides, carbonates, nitrates, ammonia; sulphates of potassium, sodium and calcium. The secretion is often called as "fluid produced from calyx hydathodes instead of nectar".-2 The cuplike water calyces serve merely as defense tool in deterring floral herbivores and in protecting the sex organs during unfavorable consequences of strong transpiration. ${ }^{2-4}$ The fluid has been demonstrated to possess antimicrobial and multi-potential biomolecules necessary for the development. ${ }^{5}$ Primary metabolites are involved in plethora of cellular reactions resulting in the overall growth of the plant body. ${ }^{6}$ Sugars in plant act as a signaling molecule and are required for the development of reproductive structures. ${ }^{7}$ Amino acids are the fundamental basic component of proteins in plants besides its cellular signaling. ${ }^{6}$ Amino acid metabolism plays a key role in protein synthesis, flower initiation, development and floral differentiation as these are the only endogenous nitrogenous compounds available within the plants. $^{8}$ Phenolics play a vital role in pigment production and plant protection from biotic and abiotic stress. ${ }^{9}$ Plant growth hormone auxin is involved in cell fate and many organ and flower development. ${ }^{10,11}$ Significant information is provided on the nitrogen metabolism, enzymes and phenolic acid metabolism in S. campanulata P. Beauv. ${ }^{12-14}$ However, the existing knowledge on the biochemical composition of aforementioned molecules in the fluid and its physicochemical properties are fragmented except mineral content and antimicrobial activity. Hence, the present work was undertaken to provide a systematic account of bio-physicochemical composition in the water calyx fluid of S. campanulata and its role during the course of flower development.

\section{MATERIAL AND METHODS}

\section{Flower collection and water calyx sample preparation}

Flower buds of $S$. campanulata were collected from different locations in the city of Bengaluru where the tree is planted as an avenue tree owing to its ornamental value. The work was carried out with freshly collected materials in two different flowering seasons. The healthy buds were selected and grouped into small, medium and large sizes based on the size cum weight of intact flower buds. The calyx fluid was extracted from the respective flower buds with the help of sterile syringes. For physicochemical study, calyx fluid from all the bud sizes were collected freshly, mixed and analyzed.

\section{Qualitative test for biomolecules ${ }^{15}$}

\section{Test for reducing sugars}

\section{Benedict's reagent method}

To $1 \mathrm{ml}$ of sample, $1 \mathrm{ml}$ of Benedict's reagent was

Cite this article: Martin Paul A, Jayanthi D, Thamizhseran N. Bio-Physicochemical Studies on Water Calyx Fluid in the African Tulip Tree, Spathodea campanulata P. Beauv. Pharmacog J. 2019;11(3):594-9 
added and heated in a boiling water bath for $10 \mathrm{~min}$. The formation of red/yellow precipitate was observed as positive reaction.

\section{Test for amino acids}

\section{Ninhydrin method}

To $1 \mathrm{ml}$ of sample, $1 \mathrm{ml}$ of $0.1 \%$ freshly prepared ninhydrin solution was added. The contents were mixed and boiled for $2 \mathrm{~min}$, allowed to cool. The appearance of violet/purple complex was observed as positive reaction.

\section{Test for proteins}

\section{Biuret reaction}

To $2 \mathrm{ml}$ of sample, $2 \mathrm{ml}$ of $10 \%$ sodium hydroxide was added followed by 2 drops of $0.1 \%$ copper sulphate solution and mixed thoroughly. The formation of violet colour was observed as positive reaction.

\section{Test for ammonia ${ }^{16,17}$}

It was carried out using Nessler's method, using a test kit for ammonia estimation. $1 \mathrm{ml}$ of the fluid from the water calyces of different bud sizes were taken in test tubes, mixed with $1 \mathrm{ml}$ of Nessler's reagent and the colour reaction and precipitation was observed.

\section{Quantitative estimation of biomolecules ${ }^{15}$}

\section{Estimation of reducing sugars}

Reducing sugars were estimated by Nelson-Somogyi method. To $1 \mathrm{ml}$ of fresh fluid, $1 \mathrm{ml}$ of fresh alkaline copper tartarate reagent was added. The mixture was heated for $20 \mathrm{~min}$ in a boiling water bath, cooled and 1 $\mathrm{ml}$ of arseno molybdate reagent was added. The solution was mixed and diluted to $25 \mathrm{ml}$ with distilled water. The resulting blue colour was read at $620 \mathrm{~nm}$ using Genesys visible spectrophotometer. $1 \mathrm{ml}$ of distilled water with all other reagent except sample was used as blank. Reducing sugars in the samples were calculated from glucose standards.

\section{Estimation of total free amino acids}

Total free amino acids were estimated by Ninhydrin method. To $1 \mathrm{ml}$ of fresh sample, $1 \mathrm{ml}$ of Ninhydrin reagent was added. The tube was heated in a boiling water bath for $20 \mathrm{~min}$, cooled to room temperature. $5 \mathrm{ml}$ of diluents solution (equal volume of water and n-propanol) was added and mixed. The volume was raised to $25 \mathrm{ml}$ with distilled water and the intensity of purple colour was read using Genesys visible spectrophotometer at $570 \mathrm{~nm} .1 \mathrm{ml}$ of distilled water with all other reagent except sample was used as blank. Total amino acids in the fluid was calculated from glycine standards.

\section{Estimation of proteins}

Proteins were estimated by Lowry's method. To $1 \mathrm{ml}$ of sample $5 \mathrm{ml}$ of alkaline copper solution was added mixed well and allowed to stand for $10 \mathrm{~min}$ at room temperature. $0.5 \mathrm{ml}$ of folin-ciocalteau reagent was added, mixed and incubated at room temperature in dark for $30 \mathrm{~min}$. The volume was raised to $25 \mathrm{ml}$ with distilled water. The intensity of the blue coloured complex was read using Genesys visible spectrophotometer at $660 \mathrm{~nm} .1 \mathrm{ml}$ of distilled water with all other reagent except sample was used as blank. Proteins in the fluid was calculated from bovine serum albumin (BSA) standards.

\section{Estimation of total phenols}

Total phenols were estimated by Folin-Ciocalteu reagent. To $1 \mathrm{ml}$ of Folin-Ciocalteu reagent $1 \mathrm{ml}$ of fresh sample was added, followed by $2 \mathrm{ml}$ of $20 \%$ sodium carbonate. The mixture was heated in boiling water bath for one min. The volume was raised to $25 \mathrm{ml}$ with distilled water and the intensity of blue colour was read using Genesys visible spectrophotometer at $725 \mathrm{~nm}$. $1 \mathrm{ml}$ of distilled water with all other reagent except sample was used as blank. Total phenols in the fluid was calculated from catechol standards.

\section{Estimation of Indole Acetic Acid ${ }^{18}$}

IAA was estimated by Salkowski's reagent method. $1 \mathrm{ml}$ of fluid was mixed with $2 \mathrm{ml}$ of Salkowski's reagent ( $0.5 \mathrm{M}$ ferric chloride in $35 \%$ perchloric acid). The tubes were mixed well and incubated in dark for $30 \mathrm{~min}$. The absorbance was recorded at $530 \mathrm{~nm}$ using Genesys visible spectrophotometer. $1 \mathrm{ml}$ of distilled water with all other reagent except sample was used as blank. IAA concentration in the fluid were obtained using standard curve of synthetic IAA from Himedia.

\section{Physiochemical analysis}

The collected fluid was analyzed for $\mathrm{pH}$, mobility, zeta potential, polarity, conductivity and viscosity using particle size analyzer (Make Microtrac, Model Nanotrac wave, USA). Density of the fluid was calculated by specific gravity method. ${ }^{19} \mathrm{pH}$ of the fluid was determined by using (Make Elico, Model LI-614 $\mathrm{pH}$ analyser).

\section{Statistical analysis}

One-way ANOVA was used for comparing means ( $\mathrm{p}<0.05)$ IBM SPSS Statistics, version 20. Tukey HSD Post Hoc test was conducted for multiple comparison study.

\section{RESULTS}

The mean concentration of biomolecules viz., reducing sugars, total free amino acids, proteins, total phenols and IAA were found to be significant at $(p<0.05)$ across the maturity of the buds. The inference of physicochemical study reveals that the water calyx fluid is highly stable

\section{Biochemical estimations}

For reducing sugars (Figure 1), mean was significant with $\left(F_{2^{\prime} 6}=\right.$ $273.160, p=0.00)$. A Tukey post hoc test revealed that the concentration of the reducing sugars statistically significantly lowered with the maturity of large buds $(268.73 \mu \mathrm{g} / \mathrm{ml} \pm 31.53, \mathrm{p}=0.00)$ and medium buds $(599.63 \mu \mathrm{g} / \mathrm{ml} \pm 18.25, \mathrm{p}=0.02)$ compared to the concentration of small buds $(727.75 \mu \mathrm{g} / \mathrm{ml} \pm 22.80, \mathrm{p}=0.00)$.

Changes in total free amino acids (Figure 2) was statistically significantly between groups $\left(\mathrm{F}_{2,6}=46.38, \mathrm{p}=0.00\right)$ and within groups concentration decreased statistically significantly with maturity of large buds $(3.31 \mu \mathrm{g} / \mathrm{ml} \pm 1.76, \mathrm{p}=0.00)$ and medium buds $(6.73 \mu \mathrm{g} /$ $\mathrm{ml} \pm 1.68, \mathrm{p}=0.02)$ compared to concentration of small buds $(14.21$ $\mu \mathrm{g} / \mathrm{ml} \pm 0.24, \mathrm{p}=0.02)$.

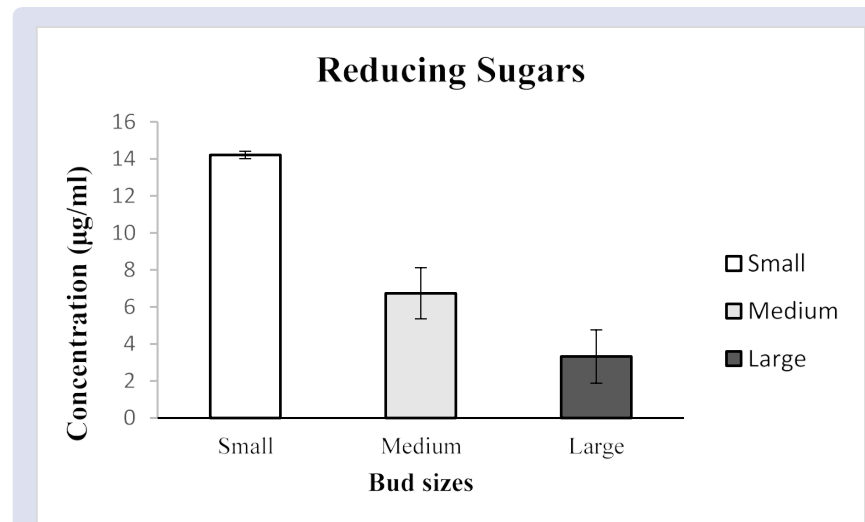

Figure 1: Concentration of reducing sugars in 3 different stages of floral development. 
Concentration of proteins (Figure 3) showed statistically significant between groups $\left(\mathrm{F}_{2,6}=134.26, \mathrm{p}=0.00\right)$ and multiple comparison revealed that within the groups concentrations of proteins decreased statistically significantly with maturity of large buds $(23.74 \mu \mathrm{g} / \mathrm{ml} \pm$ $5.51, \mathrm{p}=0.00)$ and medium buds $(58.84 \mu \mathrm{g} / \mathrm{ml} \pm 10.94, \mathrm{p}=0.00)$ when compared with small buds $(123.15 \mu \mathrm{g} / \mathrm{ml} \pm 4.48, \mathrm{p}=0.00)$.

Composition of total phenols (Figure 4) was statistically significant between groups $\left(\mathrm{F}_{2,6}=24.72, \mathrm{p}=0.001\right)$ and from Tukey post hoc test concentration of total phenols within groups was statistically significantly between large buds $(0.85 \mu \mathrm{g} / \mathrm{ml} \pm 0.79, \mathrm{p}=0.01)$ and small buds $(13.26 \mu \mathrm{g} / \mathrm{ml} \pm 3.22, \mathrm{p}=0.01)$. There was no statistically significant difference between the medium buds and small buds ( $\mathrm{p}=$ 0.197); medium and large buds ( $\mathrm{p}=0.07)$.

Endogenous plant hormone IAA (Figure 5) was statistically significant between groups $\left(\mathrm{F}_{2,6}=31.10, \mathrm{p}=0.001\right)$. Within groups the concentration of IAA decreased statistically significant with large buds $(16.35 \mu \mathrm{g} / \mathrm{ml} \pm 4.07, \mathrm{p}=0.01)$ and small buds $(264.06 \mu \mathrm{g} / \mathrm{ml} \pm 57.40, \mathrm{p}$ $=0.01)$; medium buds $(77.43 \mu \mathrm{g} / \mathrm{ml} \pm 38.81, \mathrm{p}=0.03)$ and small buds $(264.06 \mu \mathrm{g} / \mathrm{ml} \pm 57.40, \mathrm{p}=0.01)$. There was no statistically significant difference between the medium buds and large buds $(\mathrm{p}=0.228)$.

\section{Physicochemical analysis}

The $\mathrm{pH}$ of the calyx fluid was found to be alkaline with a $\mathrm{pH}$ of 8.5.

The mobility and conductivity of the fluid was $-15.63 \mathrm{u} / \mathrm{s} / \mathrm{V} / \mathrm{cm}$ and $11.672 \mu \mathrm{S} / \mathrm{cm}$ respectively.

The viscosity of the fluid was $0.9 \mathrm{~m}^{2} / \mathrm{s}$ with a density of $998.01 \mathrm{Kg} / \mathrm{m}^{3}$ almost to that of water density $1000 \mathrm{Kg} / \mathrm{m}^{3}$.

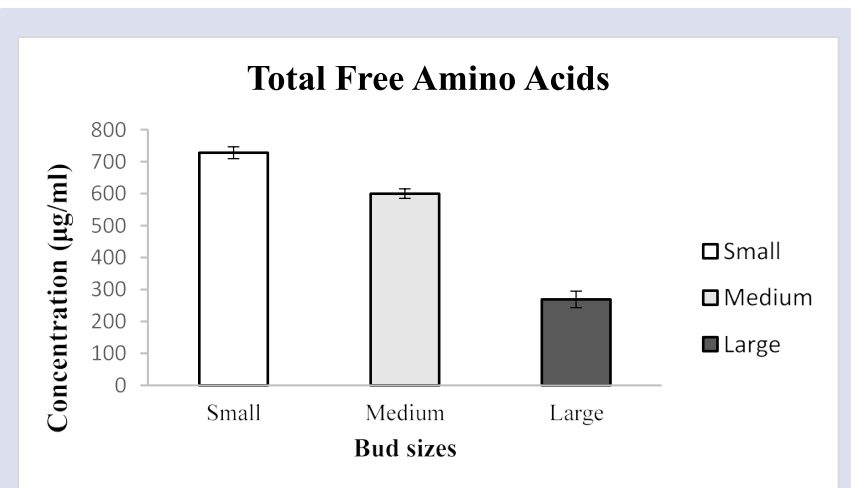

Figure 2: Concentration of amino acids in 3 different stages of floral development.

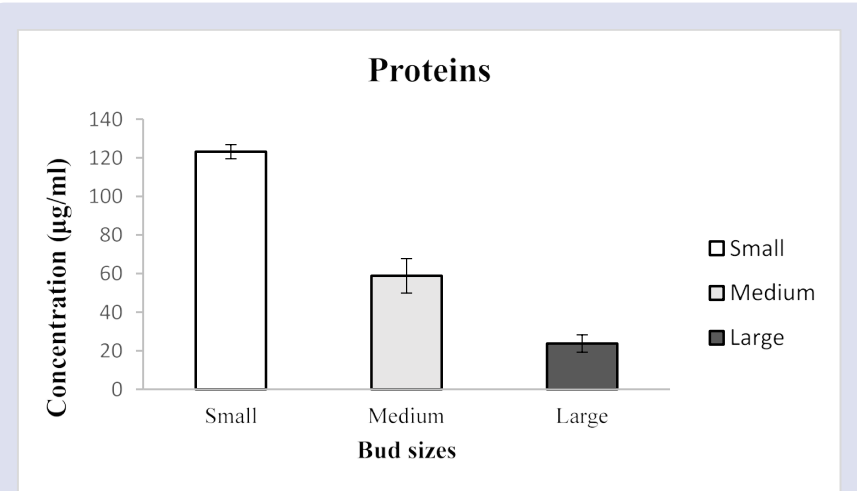

Figure 3: Concentration of proteins in 3 different stages of floral development.

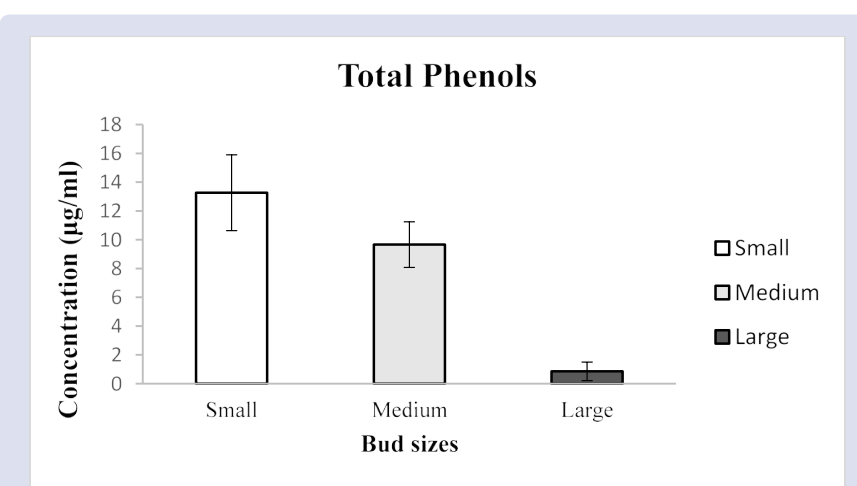

Figure 4: Concentration of total phenols in 3 different stages of floral development.

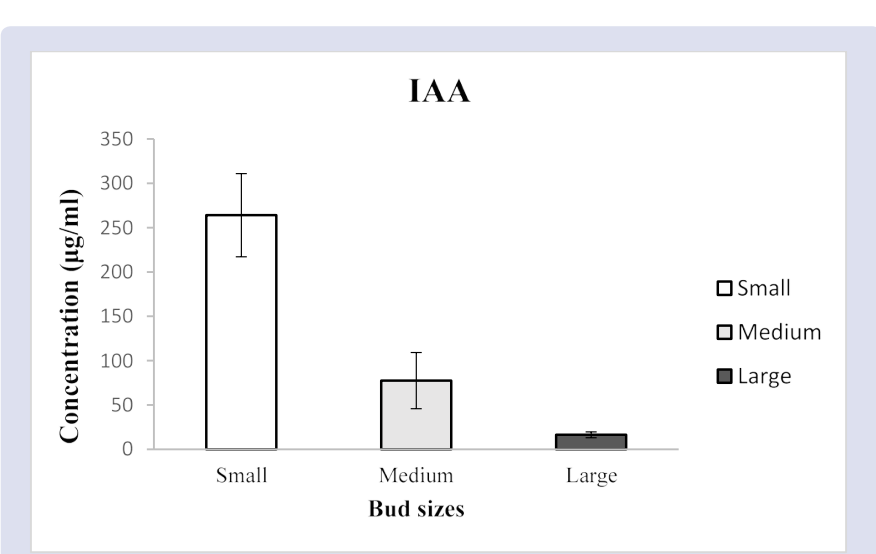

Figure 5: Concentration of IAA in 3 different stages of floral development.

The dielectric constant of the fluid was 79 at $24.53^{\circ} \mathrm{C}$ with negative polarity of charge $-3.402 \mathrm{fC}$. The dielectric constant of the fluid is almost equal to that of the dielectric constant of water i.e., 78.3 at $25^{\circ} \mathrm{C}$.

The zeta potential of the fluid was $-200.0 \mathrm{mv}$ at a $\mathrm{pH}$ 8.5.

\section{DISCUSSION}

The preliminary qualitative analyzes of biomolecules viz., reducing sugars, total free amino acids, proteins, total phenols and ammonia showed positive reaction irrespective of bud maturity. The quantitative estimations of aforementioned biomolecules except ammonia were screened and were found to be varying in concentrations irrespective of the bud maturity. A statistically significant difference between groups was determined by one-way ANOVA $(\mathrm{p}<0.05)$ in the mean concentrations of all the screened biomolecules quantitatively.

Carbohydrate metabolism is linked with the development of flowers and maturity of the flowering and other storage organs. ${ }^{20,21}$ Reducing sugars are usually found to be in abundance during the flower development as per the study. ${ }^{21-23}$ The higher content of reducing sugars in small buds is due to sucrose catabolism into glucose and fructose which generally is utilized by the plants during respiration for the production of energy so that it could be used in the floral development and blooming by forming intermediate metabolites. ${ }^{24}$

The reported concentration of amino acids corresponds to the 15 reported amino acids. ${ }^{12}$ The amino acids are believed to be declining as the flower develops. ${ }^{23}$ The amount of amino acid recorded would have pumped through vascular tissues from the root-source to the sinkflower. There are evidences amino acids could also synthesized through de novo pathways. ${ }^{25}$ The fluid acts as amino acids pool which are used as building blocks during the flower development for the synthesis of 
enzymes and structural proteins. These amino acids could also be the reason behind the ammonical nature of the calyx fluid. In vitro studies have shown floral development enhanced with exogenous application. ${ }^{26}$

A significant decline in soluble protein content during flower development reported correlates with the present study. ${ }^{23}$ Initial increase in the concentration of proteins implies that increased protein synthesis during bud development and thereafter declining trend in protein concentration is apparent in flower opening and cell expansion. ${ }^{27}$

Our results on phenols are partly in conformity with earlier reports but decrease in phenolics concentration occurred as the bud maturity increased. ${ }^{23}$ Phenols are secondary compounds having antioxidant properties basically protecting the cells from oxidative damage. ${ }^{28} \mathrm{High}$ phenol content in the calyx fluid during the early bud development stages would be beneficial for the differentiating floral tissues as it could be protecting the growing regions of the floral tissues in unopened flower buds. The variation in the phenol concentration merely does not depend on petal expansion but also on environmental and physiological cues as relevant in the present study. ${ }^{29}$

Many studies are conducted on the impact of IAA on flower development. One such example is of Arabidopsis thaliana suggesting endogenous auxin are important factor in the differentiation and formation of floral meristem and similarly high amount of IAA was also evaluated in Raphanus sativus during the flowering period. ${ }^{30,31}$ The increase in endogenous IAA content during floral bud initiation and differentiation is a regular phenomenon. ${ }^{32,33}$ IAA production is at peak during flowering with its continual growth and decreases as fruitlets are formed which is congruent with the study where the concentration is found declining with the maturity of floral buds. Hence, it is very evident from the previous studies that optimum level of endogenous IAA is required for the initiation and differentiation of floral whorls which is why the calyx fluid of smaller buds have shown maximum amount of IAA when compared to the fluid of larger buds. The present findings in this regard are in conformity with the previous studies.

The $\mathrm{pH}$ of the calyx fluid was found to be alkaline with a $\mathrm{pH}$ of 8.5 is contradictory to earlier reports claiming it to be acidic with $\mathrm{pH}$ of 6.4. ${ }^{5}$ High alkalinity of the calyx fluid is due to the high concentration of amino acids under deamination reaction to form ammonia which is clear from the present study. ${ }^{6}$ The mobility and conductivity of the fluid was $-15.63 \mathrm{u} / \mathrm{s} / \mathrm{V} / \mathrm{cm}$ and $11.672 \mu \mathrm{S} / \mathrm{cm}$ respectively which is because of the presence of dissolved biomolecules since conductivity is usually a measure of both organic and inorganic molecules as. ${ }^{34}$ The presence of 7 different minerals in the fluid could have also contributed to the conductivity. The viscosity of the fluid was $0.9 \mathrm{~m}^{2} / \mathrm{s}$ with a density of $998.01 \mathrm{Kg} / \mathrm{m}^{3}$ almost to that of water density $1000 \mathrm{Kg} / \mathrm{m}^{3}$. Water is the only solvent that is used by the plant cell for maintaining its hydrostatic pressure within cells for the movement of water and solutes in xylem and phloem and also for plant support. ${ }^{35}$ Thus, calyx fluid also conducts properties as of water in the developing flower buds for maintaining the turgidity of the floral whorls. The dielectric constant of the fluid was 79 at $24.53^{\circ} \mathrm{C}$ with negative polarity of charge $-3.402 \mathrm{fC}$. The dielectric constant of the fluid is almost equal to that of the dielectric constant of water i.e., 78.3 at $25^{\circ} \mathrm{C} .{ }^{36}$ Hence the fluid is a good solvent for charged particles with polarity of negative with a charge of $-3.402 \mathrm{fC} .{ }^{35}$ The stability of the calyx fluid was assessed through zeta potential. The zeta potential of the fluid was $-200.0 \mathrm{mv}$ at a $\mathrm{pH}$ 8.5. Since the zeta potential value is more than $-25 \mathrm{mv}$, it creates an ideal optimum environment with great stability of biomolecules which in turn could be utilized by the developing floral buds. ${ }^{37}$ Zeta potential is not only dependent on $\mathrm{pH}$ but also by the amount of ions in the dispersed medium which is why the conductivity of the calyx fluid was found to be greater and alkaline in nature. ${ }^{38}$

The water calyx fluid may be playing a major role in the development of floral parts as it was present and analyzed to contain many biochemical in appreciable quantity in all three different stages of flower development. Presence of reducing sugars, total free amino acids, proteins, total phenols and IAA were biochemically established. A significant decrease in the concentrations of all the screened biomolecules was evident from small to large sized buds owing to its utilization by the developing flower buds as immediate source for various physiological activities. The studied biomolecules confer various physiological and pharmaceutical advantages as in many plants. ${ }^{39}$ The present findings therefore prove that osmolytes of the fluid are obligatory for the development of the floral buds and fruits. Identification of all biomolecules in the water calyx fluid will throw light on its role in floral development.

\section{ACKNOWLEDGEMENT}

The authors are thankful to St. Joseph's College (Autonomous), Bengaluru for providing us lab facilities in carrying out our research work. We also thank Dr. Jayashankar M, St. Joseph's College (Autonomous), Bengaluru, for his critical inputs in drafting the paper. We would also extend our thanks to Mr. Adarsh Kumar HK, Technical officer (G-I), UPE-Research Lab, Vijnana Bhavan, Manasagangotri, Mysore for helping us in physicochemical analyses.

\section{CONFLICT OF INTEREST}

The authors declare no conflict of interest.

\section{ABBREVIATIONS}

IAA: Indole-3-Acetic Acid.

\section{REFERENCES}

1. Wilson JK. Bacterial symbiosis in plants other than the legumes. Journal of the American Society of Agronomy. 1924;374-80.

2. Burck W. Contribution to the knowledge of water-secretion in plants. II Secretion of water in the flower, in: KNAW, Proceedings, 12, Amsterdam, 1910;400-17.

3. Trigo JR, Santos WFD. Insect Mortality in Spathodea campanulata Beauv. (Bignoniaceae) flowers. Rev Brasil Biol. 2000;60(3):537-38.

4. Jane EC, Kyle EH. The benefits of bathing buds: water calyces protect flowers from a microlepidopteran herbivore. Biol Lett. 2007;3(4):405-7.

5. Killedar SG, Kope KI, Sangle SB, Tamboli MS. Standardization and antimicrobial activity of watery fluid at floral base of Spathodea campanulata (Pal). Asian Journal of Pharmaceutical Analysis. 2011;1(1):19-21.

6. Hildebrandt TM, Nunes Nesi A, Arau'jo WL and Braun HP. Amino Acid Catabolism in Plants. Mol Plant. 2015;8:1563-79.

7. Kraus EJ, Kraybill HR. Vegetation and reproduction with special reference to the tomato. Station bulletin (Oregon Agricultural Experiment Station). Corvallis. OR: Oregon Agricultural College Experiment Station. 1918.

8. Saneyuki K, Wanyi C. Analysis of nitrogen and amino acid contents in cut and potted flowers of Eustoma grandiflorum. J Japan Soc Hort Sci. 2008;77(2):1928.

9. Amita B, Priyanka S, Citovsky V. The roles of plant phenolics in defence and communication during Agrobacterium and Rhizobium infection. Molecular Plant Pathology. 2010;11(5):705-719.

10. Cheng $Y$, Zhao Y. A role for auxin in flower development. J. Integr. Plant Biol 2007; 49(1):99-104

11. Rozov SM, Zagorskaya AA, Deineko EV, and Shumny VK. Auxins: Biosynthesis, Metabolism, and Transport. Biology Bulletin Reviews. 2013;3(4):286-95.

12. Charyulu NVN, Rao KVN. Changes in the nitrogen metabolism during growth and development of the flower in Spathodea companulata Beauv. Indian J Plant Physio. 1990;33(1):7-15.

13. Charyulu NVN, Rao KVN. Changes in certain enzymes of phosphate metabolism during growth and development of the flower in Spathodea companulata Beauv. Plant Physiology and Biochemistry, New Delhi. 1995;22:59-63.

14. Charyulu NVN, Rao KVN. Phenolic acid metabolism and flower development in Spathodea companulata Beauv. Plant Physiol Biochem. 1995;22:108-14.

15. Sadasivam S, Manickam A. Biochemical methods for agricultural sciences. $3^{\text {rd }}$ ed. New Age International Publishers. 2008:270.

16. James GC, Natalie S. Microbiology a laboratory manual, fourth edition, Addison Wesley. 1999;59-75. 
17. San SY, Zaw KL, Ei, PK, Tin ML. Accumulation of ammonia in culture broth by wild-type nitrogen fixing bacterium, Stenotrophomonas maltophilia. International Journal of Applied biology and Pharmaceutical technology. 2011;72-7.

18. Gordon SA, Weber RP. Colorimetric estimation of indole acetic acid. Plant Physiol. 1951;26:192-5

19. Yadav JB. Advanced practical physical chemistry. Goel Publishing House. Meerut, India. Sixth edition, 1996;47-49.

20. Tognetti JA, Pontis HG, Martinez NGMA. Sucrose signaling in plants. Plant Signal Behav. 2013;8:3: e23316

21. Alice T, Antonio F, Paolo V, Giulia C, Giovanni S. Spatial and temporal distribution of mineral nutrients and sugars throughout the lifespan of Hibiscus rosasinensis L. flower. Cent Eur J Biol. 2011;6(3):365-75.

22. Aloni B, Karni L, Zaidman Z, Schaffer AA. Changes of carbohydrates in pepper (Capsicum annuum L.) flowers in relation to their abscission under different shading regimes. Annals of Botany. 1996;78:163-8.

23. Syed SA, Inayatullah T. Increased oxidative stress, lipid peroxidation and protein degradation trigger senescence in Iris versicolor L. flowers. Physiol Mol Biol Plants. 2016;22(4):507-14.

24. Mirelle N, Ana MM and Márcia MT. Carbohydrate metabolism in floral structures of Lilium pumilum in different development stage. Ciência Rural. 2006;46(7):1142-4.

25. Monica B, Alisdair RF. Floral metabolism of sugars and amino acids: Implications for pollinators' preferences and seed and fruit set. Plant Physiology. 2017; 175:1510-24

26. Karima MG, Abd EMSA. Effect of some amino acids on growth and essential oil content of Chamomile plant. Int J Agri Biol. 2005;7(3):376-80.

27. Olley CM, Joyce DC, Irving ED. Changes in sugar, protein, respiration and ethylene in developing and harvested Geraldton waxflower (Chamelaucium uncinatum) flowers. New Zealand Journal of Crop and Horticultural Science. 1996:24(2):143-50
28. Saboonchian F, Jamei R, Hosseini SS. Phenolic and flavonoid content of Elaeagnus angustifolia L. (leaf and flower). Avicenna J Phytomed. 2014;4(4):231-8.

29. Rana NUR, Yaohua Y, Chengquan Y, Abdul RK, Pengmin L, Fengwang M. Characterization of phenolic compounds and active anthocyanin degradation in crabapple (Malus orientalis) flowers. Hortic Environ Biotechnol. 2017;58(4):32433.

30. Goodwin PB. Phytohormones and growth and development of organs of the vegetative plant. In phytohormones and related compounds: A comprehensive treatise, Volume II. Edited by Letham, D.S., Goodwin, P.B. and Higgins, T.J.V. Elsevier/North-Holland Biomedical Press, Amsterdam.1978;31-173.

31. Mariko O, Kensuke M, Kiyotaka O, Junichi U. Auxin polar transport and flower formation in Arabidopsis thaliana transformed with Indoleacetamide Hydrolase (iaaH) gene. Plant Cell Physiol. 1999;40(2):231-7.

32. Hasan B. Correlations between changes in the amount of endogenous phytohormones and flowering in the safflower (Carthamus tinctorius L.) $\mathrm{Tr}$ Biol. 1998:22:421-5.

33. Kojima K, Shiozaki K, Koshita Y, Ishida M. Changes of endogenous levels of ABA, IAA and GA-like substances in fruitlets of parthenocarpic persimmon [Diospyros kaki]. Japanese Society for Horticultural Science. 1999;68(2):242-7.

34. Water quality field guide. PASCO scientific. 2010; 165. http://woodlandhighag weebly.com/uploads/1/9/2/9/19299463/wqfg.pdf

35. Park SN. Physicochemical and environmental plant physiology, $4^{\text {th }}$ ed, Academic press. 2009;604.

36. Malmberg CG, Maryott A. Dielectric Constant of water from $0^{\circ}$ to $100^{\circ} \mathrm{C}$ Journal of Research of the National Bureau of Standards. 1956;56(1):1-8.

37. Zeta potential analysis of nanoparticles. 2012. V 1.1. NanoComposix. https:// cdn.shopify.com/s/files/1/0257/8237/files/nanoComposix_Guidelines_for Zeta_Potential_Analysis_of_Nanoparticles.pdf.

38. Peter M, David F. Zeta Potentials of nanoceramic materials -measurement and interpretation. http://www.laborchemie.com/data/ZetaPot_Nanoceramic.pdf.

39. Ogundare CO. Phytochemical and physicochemical analysis of three different types of Apples. IJSRR. 2014;3(1):67-78.

\section{GRAPHICAL ABSTRACT}

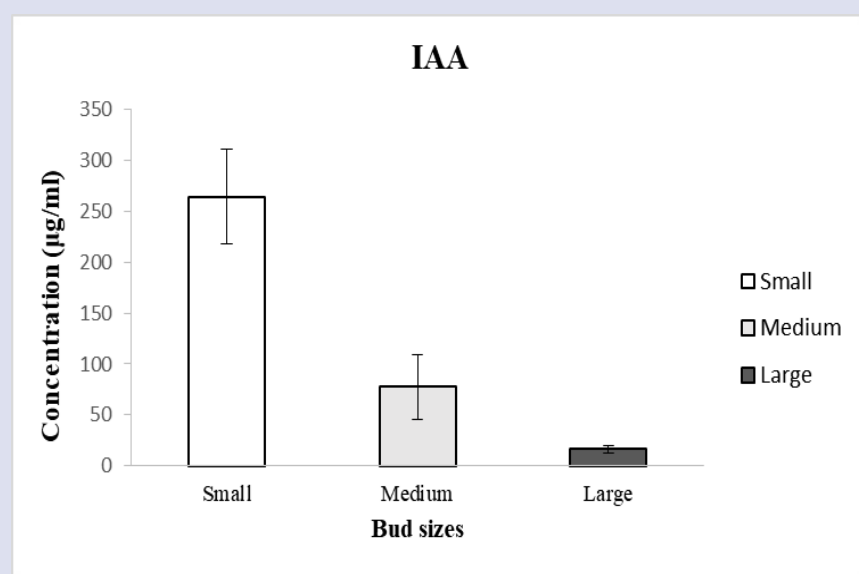

\section{SUMMARY}

Metabolites in water calyx fluid of $S$. campanulata P. Beauv. are favorable osmolytes (reducing sugars, total amino acids, protein, total phenols and (AA) and obligatory for flower development. The evaluated biomolecules are significant in quantity in various stages of floral buds and contribute to floral ontogeny. Physiochemical parameters revealed the fluid is highly stable. Hence, the water calyx fluid provides optimum physiological condition for the developing floral buds.

\section{ABOUT AUTHORS}

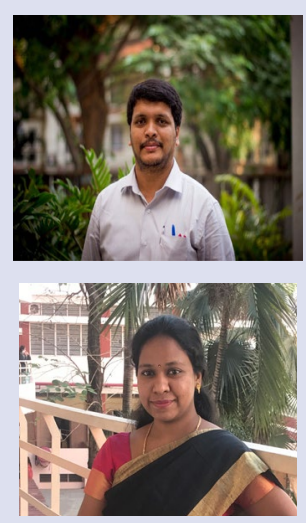

Martin Paul. A: Research Scholar, R\&D Centre, Bharathiar University, Coimbatore - 641046

Jayanthi. D: Research Scholar, R\&D Centre, Bharathiar University, Coimbatore - 641046 
Dr.Thamizhseran. N: Associate Professor, Department of Botany, St. Joseph's College (Autonomous), Bengaluru specialized in Physiological Plant Pathology and Plant-microbe interaction.

Cite this article: Martin Paul A, Jayanthi D, Thamizhseran N. Bio-Physicochemical Studies on Water Calyx Fluid in the African Tulip Tree, Spathodea campanulata P. Beauv. Pharmacog J. 2019;11(3):594-9. 